\title{
The Analysis Quality of Inpatient Room Service to Patient Satisfaction (Case Study of Saparua General Hospital)
}

\author{
Marinus Hanry Siahainenia ${ }^{1}$, Amran Razak ${ }^{2}$, Indar ${ }^{2}$, \\ Muhammad Alwy Arifin ${ }^{2}$, Arifin Seweng ${ }^{3}$, Muh Asdar ${ }^{4}$, Anwar Mallongi ${ }^{5}$ \\ ${ }^{1}$ Magister Program Department of Health Administration and Policy, Public Health Hasanuddin University, \\ ${ }^{2}$ Department of Health Administration and Policy, Public Health Hasanuddin University, ${ }^{3}$ Departement \\ Biostatisticsc, Public Health Hasanuddin University, ${ }^{4}$ Faculty of economics and business, Hasanuddin University, \\ ${ }^{5}$ Departement of Environmental Health, Public Health, Hasanuddin University, Makassar
}

\begin{abstract}
A hospital is good generally considered if in providing services it pays more attention to the needs of patients and other people visiting the hospital. The purpose of this study was to analyze the service quality of inpatient room staff on patient satisfaction at the Saparua Regional General Hospital. This type of research used in this research is quantitative research with a cross sectional design. The population in this study were all inpatients at Saparua General Hospital. The samples were determined by means of incidental sampling, namely the technique of determining the sample based on chance, that is, anyone who incidentally was admitted to an inpatient at Saparua General Hospital. The results showed that there was an effect of doctor's service on the satisfaction level of inpatients at Saparua Hospital ( $p$ value $=0.016$ ). There was no significant effect of nursing care on the satisfaction level of inpatients at Saparua Hospital ( $p$ value $=0.134$ ). the better the level of patient satisfaction. In order to improve the quality of human resources, especially in terms of increasing the quantity and quality of services, hospital staff need to provide training for doctors and nurses so that the services provided to patients can be better so that patients feel satisfied.
\end{abstract}

Keywords: Quality, Service officer, hospitalization, satisfaction, patient.

\section{Introduction}

Hospitals are a comprehensive form of health care organization covering aspects of health promotion, prevention, healing, and recovery for all communities that often face problems concerning patient dissatisfaction with the quality of service. Therefore, hospitals as facilitators of health services, in addition to comprehensive are also expected to provide quality health services that refer to the level of perfection of the health service ${ }^{1}$. Quality should be viewed more widely, where not only aspects are determined but also include

\footnotetext{
Correspondent Author:

Marinus Hanry Siahainenia

Magister Program Department of Health Administration and Policy, Public Health Hasanuddin University e-mail:marhansia3@gmail.com
}

processes, environment and humans, quality is a dynamic condition related to products, services, people, processes and environments that meet or exceed expectations. ${ }^{2}$

In the face of patient satisfaction, inevitably the provision of hospital services must maintain the quality of service continuously. Services have been patientoriented but not in the view of healthcare providers. The size of the quality of the service provider can be seen from the service received by the patient whether it is in accordance with what has been expected. ${ }^{3]}$ The quality of service has a positive and significant relationship with patient satisfaction levels, thus indicating that high levels of patient satisfaction are influenced by the high quality of service provided. The quality of service should start from the needs of the patient and end in the patient's expectations. $^{4]}$

In this study, researchers prefer patients who were hospitalized because inpatients were more likely to 
experience hospital services because they received more services. Inpatient health services are one of the main concerns of hospitals around the world. This is because hospitalization is a service to patients entering the hospital who occupy a bed for observation, diagnosis, therapy, medical rehab or other medical services with daily supervision of a doctor. In addition, quality inpatient services are an important expectation because the perception of the quality of service aspect of a hospital is formed when the patient is treated. ${ }^{[5]}$

A hospital is good generally considered if in providing services it pays more attention to the needs of patients and other people visiting the hospital. The quality of the service as a measure of how good the level of service provided is able to match the expectations of the customer (patient). ${ }^{6}$ Based on this definition, the quality of services can be realized through the fulfillment of the needs and desires of the patient and the accuracy of his delivery to keep up with the patient's expectations. With saparua hospital motto is "Patient Satisfaction is our Pride". The purpose of this study is to analyze the quality of inpatient service to patient satisfaction at Saparua Regional General Hospital.

\section{Materials and Method}

The type of research used in this study is quantitative research with cross-sectional design. The population in this study was all inpatients at Saparua General Hospital. The samples in this study were some patients who were hospitalized during the study. The determination of the sample is done by way of incidental samples, namely the technique of determining samples based on coincidence, namely anyone who is incidentally admitted to an inpatient at Saparua General Hospital. Data collection techniques are primary data obtained through live interviews to respondents during the study using questionnaires, and secondary data is obtained from the medical records section of Saparua General Hospital.

\section{Result}

Based on table 1. The results of the study above the doctor service variable, showed that out of 42 respondents based on the doctor's services, the most were respondents who gave a sufficient assessment of the doctor's services as many as 24 people $(57.1 \%)$ and the few who gave a poor doctor service rating of 18 people $(42.9 \%)$. The nursing service showed that of the 42 respondents based on nursing services, the most were those who gave a sufficient assessment of nursing services which was 23 people (54.3\%) and the fewest who rated nursing services poorly as many as 19 people (45.2\%). Patient satisfaction, showed that of the 42 respondents based on patient satisfaction levels, the most were respondents who gave a satisfied rating of 23 people (54.8\%) and the few who gave a disgruntled rating of 19 people (45.2\%).

Table 1. Distribution of Respondents Based on Research Variables at the Saparua Regional General Hospital in 2020

\begin{tabular}{|l|c|c|}
\hline Variable & Amount (n) & Percent (\%) \\
\hline Doctor Services & & \\
Enough & 24 & 57.1 \\
Not good & 18 & 42.9 \\
\hline Nursing Services & & \\
Enough & 23 & 54.3 \\
Not good & 19 & 45.2 \\
\hline Patient Satisfaction & & \\
Satisfied & 23 & 54.8 \\
Less satisfied & 19 & 45.2 \\
\hline Total & $\mathbf{4 2}$ & $\mathbf{1 0 0 . 0}$ \\
\hline
\end{tabular}

Source: Primary Data 2020

Table 2. The Influence of Research Variables on Patient Satisfaction at the Saparua Regional General Hospital in 2020

\begin{tabular}{|c|c|c|c|c|c|c|c|}
\hline \multirow{3}{*}{ Research variable } & \multicolumn{4}{|c|}{ Patient Satisfaction } & \multirow{2}{*}{\multicolumn{2}{|c|}{ Total }} & \multirow{3}{*}{$\mathbf{P}$} \\
\hline & \multicolumn{2}{|c|}{ Satisfied } & \multicolumn{2}{|c|}{ Less satisfied } & & & \\
\hline & $\mathbf{n}$ & $\%$ & $\mathbf{n}$ & $\%$ & $\mathbf{N}$ & $\%$ & \\
\hline Doctor Services & & & & & & & \multirow{4}{*}{0.016} \\
\hline Enough & 17 & 70.8 & 7 & 29.2 & 24 & 100.0 & \\
\hline Not good & 6 & 33.3 & 12 & 66.7 & 18 & 100.0 & \\
\hline Total & 23 & 54.8 & 19 & 45.2 & 42 & 100.0 & \\
\hline
\end{tabular}




\begin{tabular}{|c|c|c|c|c|c|c|c|}
\hline \multirow{3}{*}{ Research variable } & \multicolumn{4}{|c|}{ Patient Satisfaction } & \multirow{2}{*}{\multicolumn{2}{|c|}{ Total }} & \multirow{3}{*}{$\mathbf{P}$} \\
\hline & \multicolumn{2}{|c|}{ Satisfied } & \multicolumn{2}{|c|}{ Less satisfied } & & & \\
\hline & $\mathrm{n}$ & $\%$ & $\mathrm{n}$ & $\%$ & $\mathbf{N}$ & $\%$ & \\
\hline Nursing Services & & & & & & & \multirow{4}{*}{0.134} \\
\hline Enough & 15 & 65.2 & 8 & 34.8 & 23 & 100.0 & \\
\hline Not good & 8 & 42.1 & 11 & 57.9 & 19 & 100.0 & \\
\hline Total & 23 & 54.8 & 19 & 45.2 & 42 & 100.0 & \\
\hline
\end{tabular}

Source: Primary Data, 2020

Based on Table 2 of the doctor service variables shows 24 respondents with sufficient assessment of the services of doctors who are satisfied with the quality of service as many as 17 respondents $(70.8 \%)$ and as many as 7 respondents (29.2) who were dissatisfied. Meanwhile, of the 18 respondents with poor assessment of the service of doctors who were satisfied with the quality of service as much as 6 respondents (33.3\%) and 12 respondents (66.7\%) who feel less satisfied. Statistical test results obtained $p$ value $=0.016$, because the value $\mathrm{p}<\alpha=0.016>0.05$ then Ho was rejected, this means that there is a statistically meaningful influence of variable doctor services on patient satisfaction in Saparua regional general hospital.

Based on the nurse service variables, 23 respondents with sufficient assessment of the care of nurses who were satisfied with the quality of service were 15 respondents (65.2\%) and 8 respondents (34.8) who were dissatisfied. Statistical test results obtained $\mathrm{p}$ value $=0.134$, because the value $\mathrm{p}>\alpha=0.134>0.05$ then Ho received, this means that there is no statistically meaningful influence of nurse service variables on patient satisfaction in Saparua regional general hospital.

\section{Discussion}

The quality of medical services is consistent and sustainable with the aim of meeting the expectations of patients in Saparua regional general hospital. The effect of the quality of medical services is very influential on patient satisfaction because with the good quality of medical services make a positive contribution to the embodiment of patient satisfaction. ${ }^{[7]}$ The results showed that the service of doctors with sufficient patient satisfaction, where some patients stated that satisfied with the doctor's service. Doctors at Saparua regional general hospital strive to always prioritize patients, understand the needs and desires of patients.
The doctor's service felt by patients visiting saparua area general hospital can be described that in providing the service the doctor explains well and details about the cause and effect of the patient's illness, every action in the service is always followed by a good explanation and easy to understand the patient. t's just that there are still complaints of delays in doctors conducting examinations of patients. Another study conducted by Torry et al., (2016)to determine the factors that affect health care waiting times related to patient satisfaction shows that patient satisfaction is influenced by the actual waiting time felt by the patient, and the speed of service received by the patient, whose conclusion is the main factor that prolongs the waiting time of the service and decreases patient satisfaction is the lack of optimal schedule of the doctor in charge. ${ }^{8]}$

There are several types of services in hospitals whose quality is always assessed by patients and one of them is nursing services. Nurses as professionals have the most opportunity to provide health care, especially comprehensive nursing care by helping patients meet holistic basic needs. To perform her role properly, nurses need to have skills in clarifying grades, counseling and communication. ${ }^{[9]}$ The results showed that the quality of service provided by nurses at Saparua regional general hospital was assessed by either patients or respondents. Respondents stated that officers are deft in replacing fluids, always give smiles to patients who come and officers are not picky or indiscriminate in serving and assisting patients. Respondents who were dissatisfied with the nursing services at Saparua regional general hospital were concerned with the delay in nursing services. This research is not in line with Layuk et al showing the knowledge, attitude, and skills of nurses affect the satisfaction of patients in Labuang Baji Makassar Hospital, research conducted by Nahlah et al shows that there is a human relationship to inpatient satisfaction in Pelamonia Makassar Hospital ${ }^{10-15}$. 


\section{Conclusion}

The study concluded that there is an influence of physician services on the satisfaction level of inpatients in Saparua regional general hospital ( $p$ value $=0.016$ ) There is no significant effect of Nurse services on the satisfaction level of inpatients in Saparua regional general hospital ( $p$ value $=0.134$ ). the better the level of patient satisfaction. In order to improve the quality of human resources, especially in terms of improving the quantity and quality of service officers the hospital needs to provide training for doctors and nurses so that the services provided to patients can be better so that patients feel satisfied.

Ethical Clearance: Taken from University ethical committee.

\section{Source of Funding: Self}

\section{Conflict of Interest: Nil}

\section{References}

1. Soejadi, Pedoman Penelitian Kinerja Rumah Sakit Umum. Jakarta: Penerbit Katiga Bina.1996,

2. Riawaty, I., Pengaruh Kualitas Jasa Pelayanan Kesehatan Terhadap Kepuasan Pasien Rawat Inap di Rumah Sakit Umum Bahteramas Provinsi Sulawesi Tenggara Tahun 2015.

3. Palutturi, S., \& Ahri, R. A. Pengaruh Kualitas Pelayanan Terhadap Kepuasan Pasien Umum Instalasi Rawat Inap Rsud La Temmamala Soppeng Tahun 2018. Jurnal Mitrasehat, 2018; 8(2)..

4. Jacobis, R.. Faktor-Faktor Kualitas Pelayanan Pengaruhnya Terhadap Kepuasan Pasien Rawat Inap Peserta Jamkesmas Di BLU RSUP Prof. Dr. RD Kandou Manado. Jurnal EMBA: Jurnal Riset Ekonomi, Manajemen, Bisnis dan Akuntansi, 2013; 1(4)..

5. Darmawansyah, D., Indar, I., \& Tanan, L.. Analisis Tingkat Kepuasan Pasien di Puskesmas Bara Permai Kota Palopo. Jurnal Administrasi dan Kebijakan Kesehatan Indonesia, 2013; 2(03), 8230..

6. Indar, I., Noor, D. M., \& Abdullah, A. Z. Analisis Kualitas Pelayanan dan Kepuasan Pasien Rawat Inap di RSUD Kota Tarakan 2009. Media Kesehatan Masyarakat Indonesia Universitas Hasanuddin, 2010; 6(3), 27379..

7. Said, M., \& Palutturi, S. Increasing inpatient service quality of using quality function deployment method in nene mallomo hospital of sidrap regency, Indonesia. Indian Journal of Public Health Research \& Development, 2018; 9(4), 287-291.

8. Torry, T., Koeswo, M., \& Sujianto, S. Faktor yang Mempengaruhi Waktu Tunggu Pelayanan Kesehatan kaitannya dengan Kepuasan Pasien Rawat Jalan Klinik penyakit dalam RSUD Dr. Iskak Tulungagung. Jurnal Kedokteran Brawijaya, 2016; 29(3), 252-257..

9. Pangarso, F. A., Rahayu, S., \& Raharjo, D. D. T.. Analisa Budaya Kerja Prima Divisi Keperawatan Dalam Upaya Meningkatkan Kepuasan Pasien Rawat Inap Di RS. Evasari Jakarta Tahun 2018. Jurnal Bidang Ilmu Kesehatan, 2019; 9(1), 1-6.

10. Layuk, E., Tamsah, H., \& Kadir, I. Pengaruh Pengetahuan, Sikap Dan Keterampilan Perawat Terhadap Kepuasan Pasien Rawat Inap Di RS Labuang Baji Makassar. Jurnal Mirai Management, 2017; 2(2), 319-337

11. Nahlah, A., Palutturi, S., \& Abadi, M. Y. Factors Related to the Satisfaction of Patients in Pelamonia Hospital. Indian Journal of Public Health Research \& Development, 2019. 10(7): p. 5.

12. Anwar Mallongi, Stang, Syamsuar, Muh Fajaruddin Natsir, Ratna Dwi Puji Astuti, Annisa Utami Rauf, Muhammad Rachmat, Abdul Muhithd, Potential ecological risks of mercury contamination along communities area in tonasa cement industry Pangkep, Indonesia. Enfermería Clínica., Volume 30, Supplement 4, June 2020, Pages 119-122

13. Anwar Mallongi, Ezra Limbong, Furqaan Naiem, Hasanuddin Ishak, Syahrul Basri, Muh. Saleh, Aminuddin Syam, Laode Asrul. Health risk analysis of exposure to mercury $(\mathrm{Hg})$ and cyanide (CN) in Kayeli village communities Teluk Kayeli district Buru regency. Enfermería ClínicaVolume 30, Supplement 4, June 2020, Pages 427-430

14. The Investigation of the Lactic Acid Change among employee of national electrical Power Plan., SS Russeng, Lalu Muhammad saleh, DevinthaVirani, Ade Wira Listrianti Latief, Anwar Mallongi., Indian Journal of Public Health Research \& Development, 2018; 9 (1)

15. Surveillance system model for pulmonary tuberculosis suspected in Pangkep region, Indonesia. Curr.Res .M Idrus, A Mallongi, J Ibrahim. Tuberculosis, 2017; 9 (1), 1-7. 